\title{
Associations of Single Nucleotide Polymorphisms in the Bovine FADS6 Gene with Fatty Acid Composition in Hanwoo (Korean Cattle)
}

\author{
Krishnamoorthy Srikanth, Anam Kwan, Eunjin Lee, Seonkwan Kim, Youngjo Lim, \\ Hoyoung Chung* \\ Animal Genomics and Bioinformatics Division, National Institute of Animal Science, Jeonju, \\ South Korea \\ Email: "chung133@korea.kr
}

Received 15 September 2015; accepted 28 November 2015; published 2 December 2015

Copyright (C) 2015 by authors and Scientific Research Publishing Inc.

This work is licensed under the Creative Commons Attribution International License (CC BY). http://creativecommons.org/licenses/by/4.0/

(c) (i) Open Access

\begin{abstract}
The bovine fatty acid desaturase (FADS) gene cluster consists of FADS1, FADS2, FADS3, and FADS6, which acts as key enzymes in fatty acid metabolism. Of these, the genetics effects of variants in FADS1, FADS 2 and FADS 3 have been previously studied. However, the genetic effects of variants of FADS6 gene have not been studied. The aim of this study was to identify genetic variants in the bovine fatty acid desaturase 6 (FADS6) gene and study their association with fatty acid composition in Hanwoo cattle. Six genetic variants were observed, three each in intron 2 and exon 6 by DNA sequencing analyses. The association of genetic variants with fatty acid composition was evaluated in 90 Hanwoo steers. The variants were confirmed and the animals were genotyped by RFLP (Restriction Fragment Length Polymorphism) and AS-PCR (Allele Specific PCR) analyses. The analysis revealed that palmitoleic acid (C16:1n7) was associated with g.3391G $>$ A, g.3660A $>$ C and g.15657C $>\mathrm{T}$, and stearic acid (C18:0) showed highly significant association with g.3660A $>C$ segments. Both g.3391G > A, g.3660A > C also had strong additive and dominance effect for Palmitoleic acid, while g.3660A > C also had a strong dominance effect for stearic acid. These results could be useful for modulating fatty acid composition in beef and produce meat with higher monounsaturated fatty acid to saturated fatty acid ratio (MUFA/SFA), which had been shown to have positive health effect in humans.
\end{abstract}

\section{Keywords}

Fatty Acid Composition, Beef, FADS6, Genetic Association, SNP

\footnotetext{
${ }^{*}$ Corresponding author.
}

How to cite this paper: Srikanth, K., Kwan, A., Lee, E., Kim, S., Lim, Y. and Chung, H. (2015) Associations of Single Nucleotide Polymorphisms in the Bovine FADS6 Gene with Fatty Acid Composition in Hanwoo (Korean Cattle). Open Journal of Genetics, 5, 137-144. http://dx.doi.org/10.4236/ojgen.2015.54010 


\section{Introduction}

The quantity and distribution of Fatty acids (FA) in beef are directly associated with its quality and value [1]. The major FAs in cattle are myristic (C14:0), palmitic (C16:0), palmitoleic (C16:1), stearic (C18:0), vaccenic (C18:1), oleic (C18:1), and linoleic (C18:2) acids. Out of this palmitic, stearic and oleic acids make up 80\% of the FAs in beef. Oleic, palmitic, stearic, linoleic, palmitoleic and myristic acids are related to beef marbling. The composition of FA in the beef is of importance as it has a direct bearing on human health. The composition of FAs has more impact on human health than the amount of fat in the diet [2] [3]. The intake of saturated fatty acid (SFA) has a positive impact on cardio vascular diseases like atheroscleorosis whereas monounsaturated fatty acids (MUFA) and polyunsaturated fatty acids (PUFA) positively affects human health [4]-[6]. Stearic acid is considered to be neutral in its effect on plasma cholesterol in humans [7]. FA composition has become an important issue in beef industry as a major factor for determining meat quality traits. Recently, the quality of the fat has been issued as a critical factor for beef flavor, marbling degree, and colors [7] [8]. Moreover, an increased ratio of MUFA to SFA can improve the texture and taste of the meet [9]. Due to increased consumer awareness towards the implication of red meat associated fat intake on health, FA composition has become an important economic trait in the beef industry [10]. FA composition of beef is greatly influenced by age, feeding regime, and genotype [11] [12].

Animal producers have tried to change FA compositions in meat products through feeding systems that contain either high or low FA composition for their breeding goals [13] [14]. But significant difference in FA composition has been observed even when animals are fed with the same diet [15] showing genetics to play an important role in the control of FA composition. Polyunsaturated fatty acid (PUFA) is known to be involved in a variety of physiological functions [16]. The availability of PUFA in mammalian cells greatly depends on the activity of enzymes involved in FA metabolism. In mammals, the delta 5 and 6-desaturases are the pivotal enzymes introducing de novo unsaturation in the carbon chain of precursors leading to the synthesis of long-chain PUFA [17]. Bovine fatty acid desaturase (FADS) gene cluster includes FADS1, FADS2, FADS3, and FADS6, and they act as key enzymes in FA metabolism. The expression of FADS genes is correlated with eicosatetraenoic acid (C30:5n-3) and arachidonic acid (C20:4n-6) in cell culture models of cystic fibrosis. In humans, polymorphism's on FADS are known to affect omega-3 and -6 FAs concentration in plasma and tissues [18]. Genome wide association studies (GWAS) have highlighted the influence of variations in the FADS gene cluster on lipid metabolism, glucose metabolism, total cholesterol level and low-density lipoprotein in humans [19]-[21]. This is the first study to report about genetic polymorphism in FADS6 on bovine FA composition.

The aim of this study is to discover genetic variants in the entire FADS6 gene that have strong associations with FA composition in Hanwoo cattle.

\section{Materials and Methods}

\subsection{Animals and Sample Preparation}

This experiment was approved by the ethics and welfare committee of the National Institute of Animal Science (NIAS) in Korea. A total of 90 Hanwoo cattle, which were registered in the national database under the guidelines provided from NIAS, were used with average weight $(167.2 \pm 13.4 \mathrm{~kg})$ and age (206 \pm 12 day). The animals were slaughtered at the packing facility of NIAS, and the meat samples between $12^{\text {th }} \& 13^{\text {th }}$ ribs were stored in $-70^{\circ} \mathrm{C}$ until FA composition was measured.

Extraction and methylation of lipids using chloroform-methanol (2:1, v/v) were performed by the procedure of Folch and Morrison [22] [23], respectively. Fatty acid methyl esters were analyzed by a gas chromatograph (Star 3600; Varian Technologies, CA, USA) fitted with a fused silica capillary column, omega wax 205 (30 m × $0.32 \mathrm{~mm}$ i.d., $0.25 \mathrm{um}$ film thickness. The injection port and detector were maintained at $250^{\circ} \mathrm{C}$ and $300^{\circ} \mathrm{C}$, respectively, and results were presented as percentages of FAs based on the total peak area. BFT and MAR were measured between the $12^{\text {th }}$ and $13^{\text {th }}$ rib, and between the last back bone and $1^{\text {st }}$ hipbone for 3 times, respectively.

For DNA isolation, $2 \mathrm{~g}$ of muscle was chopped into $0.2 \mathrm{~cm}$ cubes and extracted with the genomic DNA E-prep kit according to the manufacturer's guideline (genomic DNA E-prep, Prepgene, Korea). To assess DNA concentration and purity, NanoDrop 1000 spectrophotometer was used (Thermo Scientific, Waltham, MA, USA). 


\subsection{PCR Amplification}

To amplify the FADS6 gene, 15 primer sets were designed based on the FADS6 genomic sequences from the UCSC genomic region (chr19:57766830 - 57782480) in Table 1. Amplifications were conducted with $10 \mathrm{X}$ reaction buffer, $2.5 \mathrm{mM}$ dNTP, $50 \mathrm{ng}$ of genomic DNA, and $0.2 \mathrm{U}$ of Taq DNA polymerase, in a final volume of $20 \mathrm{ul}$. An initial denaturation at $94^{\circ} \mathrm{C}$ for $3 \mathrm{~min}$ was followed by 35 cycles of denaturation at $94^{\circ} \mathrm{C} / 45 \mathrm{sec}$, annealing at $55^{\circ} \mathrm{C}-59^{\circ} \mathrm{C} / 1 \mathrm{~min}$, extension at $72^{\circ} \mathrm{C} / 1 \mathrm{~min}$ and a final extension at $72^{\circ} \mathrm{C} / 6 \mathrm{~min}$. The primers were designed to amplify sizes between 1000 and 1200 bp and have a GC content of $60 \%$ using PrimerSelect program of DNAStar package (version 6.1). After verification of sequences for the target segments, AS-PCR (allele-specific PCR) primers were designed to amplify approximately 500 bp segments that contain the SNP positions.

\subsection{Genotyping}

The amplified DNA fragments were purified using the PCR purification Kit (Nucleogen, Korea) and sequenced with the ABI3730 XL Genetic Analyzer (Applied Biosystems, USA) at NIAS. To confirm that the acquired sequences were from the bovine FADS6 gene, the sequence was compared with the nucleotide database through NCBI BLAST. Individual sequences were aligned with the SEQMAN program of DNAStar Package (version 6.1) to verify the SNPs. For the individual genotyping, RFLP (restriction fragment length polymorphism) and AS-PCR (Allele Specific-Polymerase chain reaction) analyses were performed. RFLP was used to detect three polymorphic sites in exon 6 with two primer sets (F1-CAGACCCCTCCCATCACAGAGC, R1-CCCCAGCG GTGGCCAGCACAG, F2-GGGCCCAACCCTGGCTCTCC, R2-AAAAAGCAAGCAGGGCAGGTGAT). The amplification reactions followed the following program, initial denaturation at $94^{\circ} \mathrm{C} / 3 \mathrm{~min}$, followed by 35 cycles of $94^{\circ} \mathrm{C} / 45 \mathrm{sec}, 57^{\circ} \mathrm{C} / 30 \mathrm{sec}, 72^{\circ} \mathrm{C} / 20$ sec and final extension at $72^{\circ} \mathrm{C} / 6 \mathrm{~min}$. The digestions with restriction enzymes (Alu I and MSP I) were performed with $2 \mathrm{ul}$ of PCR products mixed with three units of the appropriate restriction enzyme and then were incubated at $37^{\circ} \mathrm{C}$ for $2 \mathrm{~h}$. Polymorphisms in intron 2 were confirmed by AS-PCR with three primer sets (Table 2). The PCR amplification condition for the AS-PCR was an initial denaturation at $94^{\circ} \mathrm{C} / 3 \mathrm{~min}$, followed by 35 cycles of $94^{\circ} \mathrm{C} / 45 \mathrm{sec}, 59^{\circ} \mathrm{C} / 30 \mathrm{sec}, 72^{\circ} \mathrm{C} / 20 \mathrm{sec}$ and final extension at $72^{\circ} \mathrm{C} / 6 \mathrm{~min}$.

Table 1. Primer sequence for the bovine fatty acid desaturase 6 .

\begin{tabular}{|c|c|c|c|c|c|}
\hline \multirow{2}{*}{ ID } & \multicolumn{2}{|c|}{ Primer sequence } & \multicolumn{2}{|c|}{ Location } & \multirow{2}{*}{ Size (bp) } \\
\hline & Forward & Reverse & start & end & \\
\hline FADS6_1 & CGGCGGGGTCGGGTAGAT & AGGAGGTGGGGGCTGTTATGGA & 383 & 1602 & 1219 \\
\hline FADS6_2 & GCAGTTGGGGTTTGGGTTGTG & GGGGTGGCGGCGTCTGA & 1504 & 2808 & 1304 \\
\hline FADS6_3 & CCACCTGCGCACGTTTCTATTTT & GGTGGTCGGGGAGCTTGTTACT & 2248 & 3646 & 1398 \\
\hline FADS6_4 & GGCATGAGTAGGGCGAGTGGATT & GGAGCAGGCAGGCAAGGGTAGT & 3378 & 4768 & 1390 \\
\hline FADS6_5 & CCCTTGCCCACGGACTACCC & ACAGACTAAATGCCCATCAACACG & 4734 & 5805 & 1071 \\
\hline FADS6_6 & ССАСАССТТСТTТАТTCATTCACG & ACGGGGGCCAAGCTTTTAGAGAC & 5760 & 6944 & 1184 \\
\hline FADS6_7 & AAATGTACTTGCGCAGGGTCGTCT & TCCATGGGGTCACAAAAAGTCAAA & 6878 & 8103 & 1225 \\
\hline FADS6_8 & CATTGCAGGCAGATTCTTTACCAT & AGGCGCTCACCACGACTA & 7926 & 9135 & 1209 \\
\hline FADS6_9 & TGGCTGCTGGTGGAGGTCTGA & GCGGGCTTCGGGAGTCGT & 8974 & 10,331 & 1357 \\
\hline FADS6_10 & AGCAGAAGTGTGAGGAAGGAAAAC & GCGGGAGGCCAGCAAGTC & 10,168 & 11,288 & 1120 \\
\hline FADS6_11 & CCTGCGCTCGGGAACAAGA & TGCAGTGAAGAGCCAGTGAGC & 10,343 & 11,669 & 1326 \\
\hline FADS6_12 & TATTTGGTTGCATCAGGTCTTAGG & GGCCCCAGCTCCACAGTTCTT & 11,355 & 12,381 & 1026 \\
\hline FADS6_13 & TCGTGGCTGTGGGTGAGTAAG & GGGAGAAGGGCAGAAGGTAAGAGT & 12,195 & 13,282 & 1087 \\
\hline FADS6_14 & ATCTCCCTGGGCCTTTATTCTCAA & GTGGGTCCTGTGTCCGTCTCA & 13,011 & 14,275 & 1264 \\
\hline FADS6_15 & GAGGCTCAGCACAGGACACAGAAC & GCCCCGGGAAGGACAGC & 14,187 & 15,533 & 1346 \\
\hline
\end{tabular}

The sequences were based on the genomic regions (UCSC chr19:57766830 - 57782480). 
Table 2. Least squared means and standard errors for fatty acid composition with each genotype from 3 FADS6 segments.

\begin{tabular}{|c|c|c|c|c|c|c|c|c|c|c|c|}
\hline \multirow{2}{*}{ NP } & \multicolumn{3}{|c|}{ Genotype $(\mathrm{LSM} \pm \mathrm{SE})$} & \multirow{2}{*}{$\begin{array}{c}\text { Allele } \\
\text { frequency }\end{array}$} & \multirow{2}{*}{$\chi^{2}(\mathrm{HW})$} & \multirow{2}{*}{$\begin{array}{l}\text { Fatty } \\
\text { acid }\end{array}$} & \multirow{2}{*}{$P$} & \multicolumn{4}{|c|}{ Effect } \\
\hline & GG(31) & GA (53) & $\mathrm{AA}(2)$ & & & & & Additive & $\mathrm{P}$ & Dominance & $\mathrm{P}$ \\
\hline \multirow[t]{2}{*}{ g.3391G > A } & $\begin{array}{c}4925 \pm \\
0.10\end{array}$ & $\begin{array}{c}5.100 \pm \\
0.13\end{array}$ & $\begin{array}{c}3.745 \pm \\
0.52\end{array}$ & $\begin{array}{c}G=0.668 \\
A=0.3314\end{array}$ & $13.1272^{*}$ & $\begin{array}{c}\text { Palmitoleic } \\
\text { acid } \\
\text { (C16:1n7) }\end{array}$ & 0.044 & $\begin{array}{c}1.180 \pm \\
0.53\end{array}$ & 0.03 & $\begin{array}{c}1.528 \pm \\
0.60\end{array}$ & 0.012 \\
\hline & $\mathrm{AA}(2)$ & $\mathrm{AC}(65)$ & CC (19) & & & & & & & & \\
\hline \multirow[t]{2}{*}{ g. $3660 \mathrm{~A}>\mathrm{C}$} & $\begin{array}{c}3.742 \pm \\
0.52\end{array}$ & $\begin{array}{c}5.062 \pm \\
0.09\end{array}$ & $\begin{array}{c}4.750 \pm \\
0.17\end{array}$ & $A=0.401$ & \multirow[t]{2}{*}{$27.4836^{*}$} & $\begin{array}{c}\text { Palmitoleic } \\
\text { acid } \\
\text { (C16:1n7) }\end{array}$ & 0.021 & $\begin{array}{c}-1.007 \pm \\
0.55\end{array}$ & 0.07 & $\begin{array}{c}1.632 \pm \\
0.58\end{array}$ & 0.006 \\
\hline & $\begin{array}{c}12.019 \pm \\
0.74\end{array}$ & $\begin{array}{c}10.429 \pm \\
0.13\end{array}$ & $\begin{array}{c}11.208 \pm \\
0.24\end{array}$ & $C=0.598$ & & $\begin{array}{l}\text { Stearic acid } \\
\text { (C18:0) }\end{array}$ & 0.004 & $\begin{array}{c}0.811 \pm \\
0.77\end{array}$ & 0.30 & $\begin{array}{c}-2.368 \pm \\
0.82\end{array}$ & 0.005 \\
\hline $\begin{array}{c}\text { g. } 15657 \mathrm{C}> \\
\text { T }\end{array}$ & $\begin{array}{c}\text { CC (28) } \\
4.859 \pm \\
0.14\end{array}$ & $\begin{array}{c}\text { CT (48) } \\
5.113 \pm \\
0.10\end{array}$ & $\begin{array}{c}\text { TT (10) } \\
4.513 \pm \\
0.23\end{array}$ & $\mathrm{~T}=0.3953$ & 2.410 & $\begin{array}{c}\text { Palmitoleic } \\
\text { acid } \\
\text { (C16:1n7) }\end{array}$ & 0.051 & $\begin{array}{c}0.346 \pm \\
0.27\end{array}$ & 0.21 & $\begin{array}{c}0.854 \pm \\
0.34\end{array}$ & 0.016 \\
\hline
\end{tabular}

Parentheses are the numbers of animals. HW = Hardy Weinberg Equilibrium; ${ }^{*}$ Indicates significance.

\subsection{Statistical Analysis}

The FA measurements were tested for normal distributions. 10 out of 17 FAs were used for the association tests due to no measurements for the remaining FAs. The statistical analysis of associations between SNP and FA composition was performed with the GLM procedure on SAS 9.2 with a model that has a fixed effect for genotype, a covariate for age, and a random effect for sire. The genotyping frequencies and minor allele frequencies and HWE (Hardy-Weinberg Equilibrium) were calculated with Arlequin version 3.5.

\section{Results}

\subsection{Analysis of Genetic Variants}

For the analysis of genetic variants of the FADS6 gene in Hanwoo, the targeted fragments were successfully amplified with 15 primer sets, and sizes were confirmed by direct sequencing analysis. A total of 6 genetic variants were found, with 3 each at the intron number 2 (nucleotide positions 3391, 3660, and 4655) and the exon number 6 (nucleotide positions 15,527, 15,590, and 15,657) based on a reference sequence (UCSC genomic regions chr19:57766830 - 57782480) by PCR-RFLP and AS-PCR (Figure 1). The PCR-RFLP analysis (Figure 2) verified unique restriction patterns, showing DNA fragments of different mobilities by agarose gel electrophoresis. The g.15527C > T SNP in exon 6 was digested with Alu I, and g.15590T > C, and g.15657C > T SNPs in exon 6 were digested with MSP I, while the polymorphisms (g.3391G > A, g.3660A > C, and g.4655G > A) were confirmed with AS-PCR analysis. Only g.3391G > A, g.3660A > C and g.15527C > T were found to have significant association with FAs. The allele frequency and Hardy Weinberg equilibrium (HWE) were calculated for these three SNPs. The SNP g.3391G > A presented allele frequency for G (0.6686) and A (0.3313), resulting in a genotype frequency of 36.05\% (GG), 61.62\% (GA) and 2.32\% (AA) respectively. The genotype frequency at g.3660A > C was 2.32\% (AA), 74.42 (AC) and 22.09\% (CC), with allele frequencies for A being 0.4 and for $\mathrm{C}$ being 0.6 . Allele frequency at g.15527C $>\mathrm{T}$ was $\mathrm{C}(0.6046)$ and $\mathrm{T}(0.3953)$, resulting in a genotype frequency of $32.55 \%$ (CC), 55.81\% (CT) and 11.62\% (TT) respectively .The HWE for g.3391G > A, g.3660A > C were found to be highly significant $(P>0.0001)$ (Table 3$)$.

\subsection{Association Analyses}

As shown in Table 3, the analyses observed marginal associations for palmitoleic acid (C16:1n7) with g.3391G/ A $(p=0.044)$ and g.15657C/T $(p=0.051)$ whereas, genotypes of g.3660A/C showed significant associations with palmitoleic acid (C16:1n7) and stearic acid (C18:0). At g.3391G > A, the GA genotype had higher association (5.100 \pm 0.13) with Palmitoleic acid followed by GG and AA genotypes. The SNP g.3660A > C had significant association with Palmitoleic acid and Stearic acid, with the AC genotype being strongly associated 
Table 3. The targeted SNP locations, amplification sizes, and primer sequences for Allele Specific PCR.

\begin{tabular}{|c|c|c|c|c|}
\hline \multirow{2}{*}{ ID } & \multirow{2}{*}{ Primer sequence } & \multicolumn{2}{|c|}{ Size } & \multirow{2}{*}{ SNP location } \\
\hline & & Start & End & \\
\hline Uni $1 F$ & ACAGCCTGGAGGTGGGTGAG & 3150 & 3169 & \multirow{4}{*}{3392} \\
\hline Uni $1 \mathrm{R}$ & TTGGAAGCAGGCATTGAAGAGTC & 3603 & 3625 & \\
\hline ASPCR $1-1 \mathrm{~F}$ & GCCACTGGCATGAGTAGGGCG & 3372 & 3392 & \\
\hline ASPCR 1-2F & GCCACTGGCATGAGTAGGGCA & 3372 & 3392 & \\
\hline Uni $2 \mathrm{~F}$ & TCAACCAGGCAGCGGACAGT & 3412 & 3431 & \multirow{4}{*}{3661} \\
\hline Uni 2R & GCAACAGGAGAAGCCACCACAG & 3898 & 3919 & \\
\hline ASPCR 2-1F & GACСАСССССАТСАССТТТTТА & 3640 & 3661 & \\
\hline ASPCR 2-2F & GACСАСССССАТСАССТТТТТС & 3640 & 3661 & \\
\hline Uni 3F & CAGCATCACCATAGAAGAATC & 4399 & 4419 & \multirow{4}{*}{4565} \\
\hline Uni 3R & CACCCCAGCCTGCСССТАСАT & 4834 & 4854 & \\
\hline ASPCR 3-1F & ATATACСССАСТCACGCCAG & 4637 & 4656 & \\
\hline ASPCR 3-2F & ATATACСССАСТCACGCСАA & 4637 & 4656 & \\
\hline
\end{tabular}

Uni: Unique primers to amplify approximately 500 bp; Primer sequences were based on the genomic region (chr19:57766830 - 57782480, UCSC).

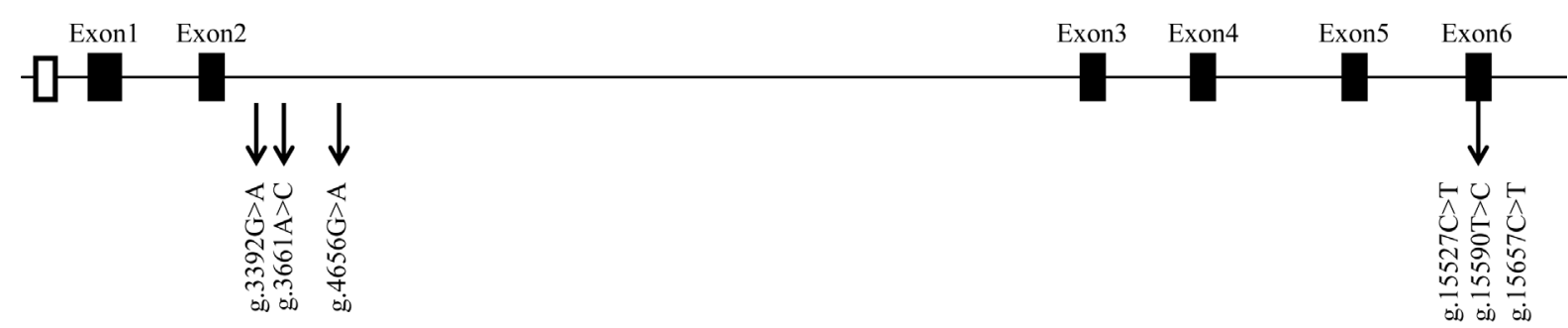

Figure 1. Gene Structure. Genetic variants have been confirmed using RFLP and AS-PCR analyses. Nucleotide positions 3392, 3661 and 4656 were located in intron 2 and 15,527, 15,590 and 15,657 were located in exon 6 based on a reference sequence (UCSC a genomic region of chr 19:57766830 - 57782480).
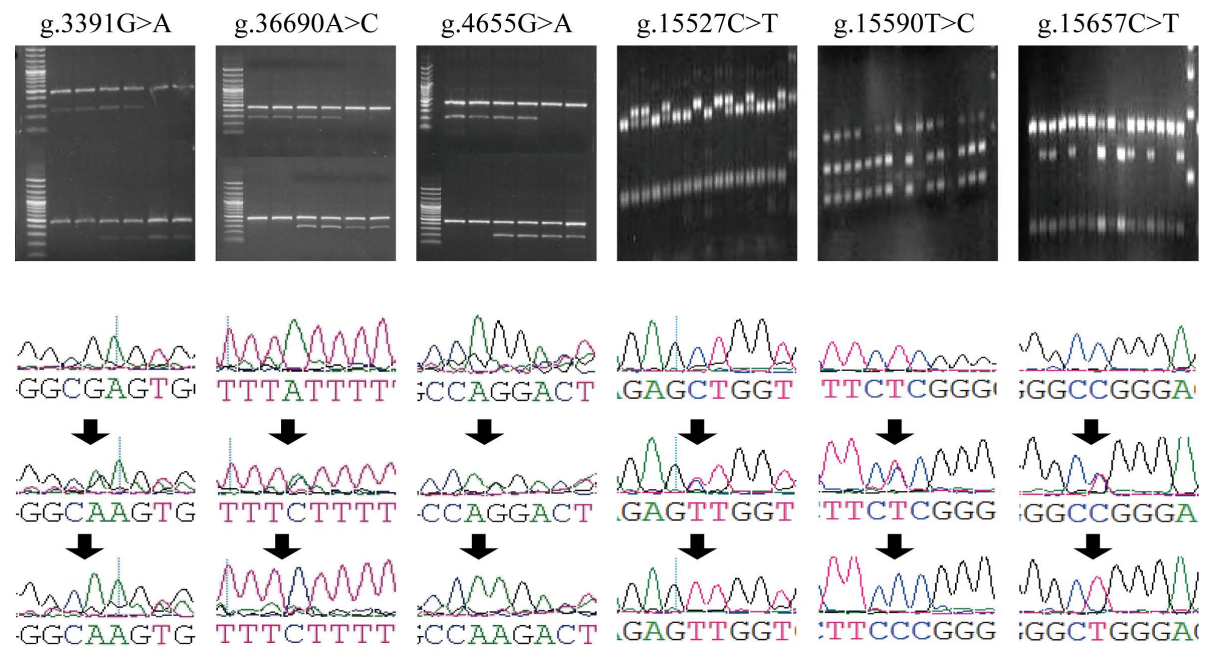

Figure 2. Detection of single nucleotide polymorphisms with RFLP and AS-PCR analyses. The segments (g.3391G > A, g.3660A > C, and g.4655G > A) were analyzed with AS-PCR and the segments (g.15527C > T, g15590T > C, and g.15657C > T) were analyzed by RFLP analyses with Alu I and MSP I restriction enzymes. 
with the former and AA being significantly associated with the later. The SNP g.15657C > T had strong association with Palmitoleic acid, with the strongest association for genotype CT followed by CC and TT. Whereas, the genotypes of g.4655G > A, g.15527C > T, and g.15590T > C were not significantly associated with FA composition. Significant dominance genetic effects were detected for all segments, additionally, additive genetic effects were found between the genotypes of g.3391G > A and Palmitoleic acid (C16:1n7).

\section{Discussion}

Increased consumption of food rich in fat particularly saturated fatty acid predisposes man to cardio vascular disease [24]. Consumers are increasingly aware about the correlation between food and health. Beef is a highly nutritious and valued food. In fact, fat like conjugated linoleic acid (CLA) which is present in beef is considered to be beneficial for human health [25]. But the high concentration of saturated fatty acid in beef leads to negative effects in human health. Several studies have tried to manipulate fatty acid composition in beef [24]-[26]. Improving the polyunsaturated fatty acid (PUFA) to saturated fatty acid (SFA) ratio is a way to produce healthier meet. PUFA and MUFA (monounsaturated fatty acids) are beneficial to human health [27]. Moreover, increasing the ratio of MUFA to SFA also leads to increase in texture and taste [9]. Studies have showed the association of polymorphism in fatty acid biosynthetic genes like SREBP01, LXR $\alpha$, FADS1, FADS2, FADS4, FASN etc. with fatty acid composition and also beef quality traits [1] [10] [28]. FADS6 (Fatty acid desaturase 6) is a member of the fatty acid desaturase family, and is involved in the fatty acid biosynthesis pathaway. No functional study of bovine FADS6 has been reported, but they are found to be highly similar to human FADS6. The FADS6 gene in humans is homologous to FADS2 [29] [30]. FADS2 synthesizes Delta-6-desaturase (D6D). D6D catalyzes the first step in the synthesis of highly unsaturated fatty acid (HUFA) or LC-PUFA (long chain-poly unsaturated fatty acid) [29] [31]. This is the first study to report the effect of genetic variants in FADS6 on fatty acid composition in beef (Hanwoo cattle). Six genetic variations were found within FADS6 out of which 3 were in the 2nd intron (nucleotide positions 3391, 3660, and 4655) and 3 were in the 6th exon (nucleotide positions $15,527,15,590$, and 15,657). Out of them, the variation at g.3391G > A and g.15657C > T was found to have significant association with the composition of palmitoleic acid. Palmitoleic acid, a MUFA is known to have a positive effect on hepatic lipid accumulation and insulin resistance [9] [32]. The SNP g.3660A $>$ C was found to have strong association $(\mathrm{P}>0.21, \mathrm{P}>0.004)$ with additive and dominance effect $(\mathrm{P}>0.07, \mathrm{P}>0.006)$ for palmitoleic acid and strong additive effect $(\mathrm{P}>0.004)$ for stearic acid respectively. Stearic acid unlike other unsaturated fatty acid (UFA) has a neutral effect on human blood cholesterol level [33] [34]. Moreover, the firmness of carcass fat and the melting point of lipids in beef are closely related to the concentration of stearic acid therby influencing the quality of the meat [35]. Bovine FADS2 was homologous to human FADS6, and SNPs in bovine FADS6 were found to have an effect on several fat related traits, and SNP FADS2 g.-823G > A was proposed as a genetic marker for beef advancement [28]. The significant associations with dominance effects for genotypes of FADS6 g.15657C > T located in exon 6 may be an important factor and could be used as genetic markers for Palmitoleic acid (C16:1n7).

\section{Conclusion}

In conclusion, the identified SNPs are the first report to help in understanding the genetic structures of FADS6 on fatty acid compositions in cattle populations. The SNPs in FADS6 were found to have a strong association with palmitoleic and stearic acid composition. These variations might help in producing healthy beef, high in MUFA and stearic acid. With stearic acid influencing both taste and texture of meat, these SNPs might also be associated with beef quality traits. This study provides useful genetic information regarding the relation between FADS6 and fatty acid composition.

\section{References}

[1] Bhuiyan, M.S.A., Yu, S.L., Jeon, J.T., Yoon, D., Cho, Y.M., Park, E.W., Kim, N.K., Kim, K.S., Lee, J.H., et al. (2009) DNA Polymorphisms in SREBF1 and FASN Genes Affect Fatty Acid Composition in Korean Cattle (Hanwoo). AsianAustralasian Journal of Animal Sciences, 22, 765-773. http://dx.doi.org/10.5713/ajas.2009.80573

[2] Hu, F.B., Manson, J.E. and Willett, W.C. (2001) Types of Dietary Fat and Risk of Coronary Heart Disease: A Critical Review. Journal of the American College of Nutrition, 20, 5-19. http://dx.doi.org/10.1080/07315724.2001.10719008

[3] Woodside, J.V. and Kromhout, D. (2005) Fatty Acids and CHD. Proceedings of the Nutrition Society, 64, 554-564. 
http://dx.doi.org/10.1079/PNS2005465

[4] Bhattacharya, A., Banu, J., Rahman, M., Causey, J. and Fernandes, G. (2006) Biological Effects of Conjugated Linoleic Acids in Health and Disease. The Journal of Nutritional Biochemistry, 17, 789-810. http://dx.doi.org/10.1016/j.jnutbio.2006.02.009

[5] Richard, D., Bausero, P., Schneider, C. and Visioli, F. (2009) Polyunsaturated Fatty Acids and Cardiovascular Disease. Cellular and Molecular Life Sciences, 66, 3277-3288. http://dx.doi.org/10.1007/s00018-009-0085-4

[6] Wolfram, G. (2003) Dietary Fatty Acids and Coronary Heart Disease. European Journal of Medical Research, 8, 321324.

[7] Melton, S.L., Amiri, M., Davis, G.W. and Backus, W.R. (1982) Flavor and Chemical Characteristics of Ground Beef From Grass-, Forage-Grain-and Grain-Finished Steers. Journal of Animal Science, 55, 77-87.

[8] Park, H.-I., Lee, M.-H. and Chung, M.-S. (1994) Comparison of Flavor Characteristics and Palatability of Beef Obtained from Various Breeds. Korean Journal of Food Science and Technology, 26, 500-506.

[9] Yang, A., Larsen, T.W., Smith, S.B. and Tume, R.K. (1999) $\Delta 9$ Desaturase Activity in Bovine Subcutaneous Adipose Tissue of Different Fatty Acid Compositiondesaturase Activity in Bovine Subcutaneous Adipose Tissue of Different Fatty Acid Composition. Lipids, 34, 971-978. http://dx.doi.org/10.1007/s11745-999-0447-8

[10] Han, C., Vinsky, M., Aldai, N., Dugan, M.E.R., McAllister, T.A. and Li, C. (2013) Association Analyses of DNA Polymorphisms in Bovine SREBP-1, LXR $\alpha$, FADS1 Genes with Fatty Acid Composition in Canadian Commercial Crossbred Beef Steers. Meat Science, 93, 429-436. http://dx.doi.org/10.1016/j.meatsci.2012.10.006

[11] Alfaia, C.M.M., Ribeiro, V.S.S., Lourenço, M.R.A., Quaresma, M.A.G., Martins, S.I.V., Portugal, A.P.V., Fontes, C., Bessa, R.J.B., Castro, M.L.F. and Prates, J.A.M. (2006) Fatty Acid Composition, Conjugated Linoleic Acid Isomers and Cholesterol in Beef from Crossbred Bullocks Intensively Produced and from Alentejana Purebred Bullocks Reared According to Carnalentejana-PDO Specifications. Meat Science, 72, 425-436. http://dx.doi.org/10.1016/j.meatsci.2005.08.012

[12] De Smet, S., Raes, K. and Demeyer, D. (2004) Meat Fatty Acid Composition as Affected by Fatness and Genetic Factors: a review. Animal Research, 53, 81-98. http://dx.doi.org/10.1051/animres:2004003

[13] Gillis, M.H., Duckett, S.K. and Sackmann, J.R. (2004) Effects of Supplemental Rumen-Protected Conjugated Linoleic Acid or Corn Oil on Fatty Acid Composition of Adipose Tissues in Beef Cattle. Journal of Animal Science, 82, 14191427.

[14] Dugan, M.E.R., Aldai, N., Kramer, J.K.G., Gibb, D.J., Juárez, M. and McAllister, T.A. (2010) Feeding Wheat Dried Distillers Grains with Solubles Improves Beef and Conjugated Linoleic Acid Profiles. Journal of Animal Science, 88, 1842-1847. http://dx.doi.org/10.2527/jas.2009-2575

[15] Dugan, M.E.R., Kramer, J.K.G., Robertson, W.M., Meadus, W.J., Aldai, N. and Rolland, D.C. (2007) Comparing Subcutaneous Adipose Tissue in Beef and Muskox with Emphasis on Trans 18: 1 and Conjugated Linoleic Acids. Lipids, 42, 509-518. http://dx.doi.org/10.1007/s11745-007-3051-7

[16] Spector, A.A. (1999) Essentiality of Fatty Acids. Lipids, 34, S1-S3. http://dx.doi.org/10.1007/BF02562220

[17] Lattka, E., Illig, T., Heinrich, J. and Koletzko, B. (2010) Do FADS Genotypes Enhance Our Knowledge about Fatty acid Related Phenotypes? Clinical Nutrition, 29, 277-287. http://dx.doi.org/10.1016/j.clnu.2009.11.005

[18] Njoroge, S.W., Seegmiller, A.C., Katrangi, W. and Laposata, M. (2011) Increased $\Delta 5$-and $\Delta 6$-Desaturase, Cyclooxygenase-2, and Lipoxygenase-5 Expression and Activity Are Associated with Fatty Acid and Eicosanoid Changes in Cystic Fibrosis. Biochimica et Biophysica Acta (BBA)-Molecular and Cell Biology of Lipids, 1811, 431-440. http://dx.doi.org/10.1016/j.bbalip.2011.05.002

[19] Kathiresan, S., Melander, O., Guiducci, C., Surti, A., Burtt, N.P., Rieder, M.J., Cooper, G.M., Roos, C., Voight, B.F., Havulinna, A.S., et al. (2008) Six New Loci Associated with Blood Low-Density Lipoprotein Cholesterol, High-Density Lipoprotein Cholesterol or Triglycerides In Humans. Nature Genetics, 40, 189-197. http://dx.doi.org/10.1038/ng.75

[20] Truong, H., DiBello, J.R., Ruiz-Narvaez, E., Kraft, P., Campos, H. and Baylin, A. (2009) Does Genetic Variation in the $\Delta 6$-Desaturase Promoter Modify the Association between $\alpha$-Linolenic Acid and the Prevalence of Metabolic Syndrome? The American Journal of Clinical Nutrition, 89, 920-925. http://dx.doi.org/10.3945/ajcn.2008.27107

[21] Tanaka, T., Shen, J., Abecasis, G.R., Kisialiou, A., Ordovas, J.M., Guralnik, J.M., Singleton, A., Bandinelli, S., Cherubini, A., Arnett, D., et al. (2009) Genome-Wide Association Study of Plasma Polyunsaturated Fatty Acids in the InCHIANTI Study. PLOS Genetics, 5, Article ID: e1000338.

[22] Folch, J., Lees, M., Sloane-Stanley, G.H., et al. (1957) A Simple Method for the Isolation and Purification of Total Lipids from Animal Tissues. The Journal of Biological Chemistry, 226, 497-509.

[23] Morrison, W.R. and Smith, L.M. (1964) Preparation of Fatty Acid Methyl Esters and Dimethylacetals from Lipids with 
Boron Fluoride-Methanol. Journal of Lipid Research, 5, 600-608.

[24] Scollan, N.D., Choi, N.-J., Kurt, E., Fisher, A.V., Enser, M. and Wood, J.D. (2001) Manipulating the Fatty Acid Composition of Muscle and Adipose Tissue in Beef Cattle. British Journal of Nutrition, 85, 115-124. http://dx.doi.org/10.1079/BJN2000223

[25] McGuire, M.A. and McGuire, M.K. (2000) Conjugated Linoleic Acid (CLA): A Ruminant Fatty Acid with Beneficial Effects on Human Health. Journal of Animal Science, 77, 1-8.

[26] Dannenberger, D., Nuernberg, K., Nuernberg, G., Scollan, N., Steinhart, H. and Ender, K. (2005) Effect of Pasture vs. Concentrate Diet on CLA Isomer Distribution in Different Tissue Lipids of Beef Cattle. Lipids, 40, 589-598. http://dx.doi.org/10.1007/s11745-005-1420-2

[27] Scollan, N., Hocquette, J.-F., Nuernberg, K., Dannenberger, D., Richardson, I. and Moloney, A. (2006) Innovations in Beef Production Systems That Enhance the Nutritional and Health Value of Beef Lipids and Their Relationship with Meat Quality. Meat Science, 74, 17-33. http://dx.doi.org/10.1016/j.meatsci.2006.05.002

[28] Matsumoto, H., Nogi, T., Tabuchi, I., Oyama, K., Mannen, H. and Sasazaki, S. (2014) The SNPs in the Promoter Regions of the Bovine FADS2 and FABP4 Genes Are Associated with Beef Quality Traits. Livestock Science, 163, 34- 40. http://dx.doi.org/10.1016/j.livsci.2014.02.016

[29] Stroud, C.K., Nara, T.Y., Roqueta-Rivera, M., Radlowski, E.C., Lawrence, P., Zhang, Y., Cho, B.H., Segre, M., Hess, R.A., Brenna, J.T., Haschek, W.M. and Nakamura, M.T. (2009) Disruption of FADS2 Gene in Mice Impairs Male Reproduction and Causes Dermal and Intestinal Ulceration. Journal of Lipid Research, 50, 1870-1880. http://dx.doi.org/10.1194/jlr.M900039-JLR200

[30] Chen, H., Hao, G., Wang, L., Wang, H., Gu, Z., Liu, L., Zhang, H., Chen, W. and Chen, Y.Q. (2015) Identification of a Critical Determinant That Enables Efficient Fatty Acid Synthesis in Oleaginous Fungi. Scientific Reports, 5, Article ID: 11247. http://dx.doi.org/10.1038/srep11247

[31] Zheng, X., Seiliez, I., Hastings, N., Tocher, D.R., Panserat, S., Dickson, C.A., Bergot, P. and Teale, A.J. (2004) Characterization and Comparison of Fatty Acyl $\Delta 6$ Desaturase cDNAs from Freshwater and Marine Teleost Fish Species. Comparative Biochemistry and Physiology Part B: Biochemistry and Molecular Biology, 139, 269-279. http://dx.doi.org/10.1016/j.cbpc.2004.08.003

[32] Bernstein, A.M., Roizen, M.F. and Martinez, L. (2014) Purified Palmitoleic Acid for the Reduction of High-Sensitivity C-Reactive Protein and Serum Lipids: A Double-Blinded, Randomized, Placebo Controlled Study. Journal of Clinical Lipidology, 8, 612-617. http://dx.doi.org/10.1016/j.jacl.2014.08.001

[33] Yu, S., Derr, J., Etherton, T.D. and Kris-Etherton, P.M. (1995) Plasma Cholesterol-Predictive Equations Demonstrate That Stearic Acid Is Neutral and Monounsaturated Fatty Acids Are Hypocholesterolemic. The American Journal of Clinical Nutrition, 61, 1129-1139.

[34] Bonanome, A. and Grundy, S.M. (1988) Effect of Dietary Stearic Acid on Plasma Cholesterol and Lipoprotein Levels. New England Journal of Medicine, 318, 1244-1248. http://dx.doi.org/10.1056/NEJM198805123181905

[35] Wood, J.D., Richardson, R.I., Nute, G.R., Fisher, A.V., Campo, M.M., Kasapidou, E., Sheard, P.R. and Enser, M. (2004) Effects of Fatty Acids on Meat Quality: A Review. Meat Science, 66, 21-32. http://dx.doi.org/10.1016/S0309-1740(03)00022-6 